\title{
偏心固視を呈した弱視の治療成績
}

\author{
中村＼cjkstart桂子・演村美恵子・野邊由美子 \\ 澤 ふみ子・菅澤淳・内海隆 \\ (大阪医科大学眼科)
}

\section{Characteristics of the effect of occlusion therapy on the amblyopes with eccentric fixation.}

\author{
Keiko NAKAmura, Mieko Hamamura, Yumiko NOBE \\ Fumiko SAWA, Jun SUGASAWA, and Takashi UTSUMI \\ Department of Ophthalmology, Osaka Medical College
}

\begin{abstract}
当院で行って来ている健眼遮閉を中心とした偏心固視の治療に関し今回その結果を検討する中から予後に 影響をおよぼす諸因子の見直しを行った。

対象は内斜視 45 例, 外斜視 9 例, 上斜視 2 例, microtropia 4 例の計 60 例で, 治療開始時年齢は 2 歳から 12

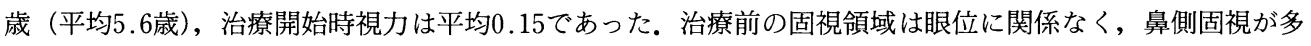
く(83\%) みられた. 治療の結果, 字ひとつ視力 $(0.8)$ 以上を得た症例は $35 \%$ \%, 治療期間は 17.1 月であっ た. しかし, 斜視のタイプや固視領域と予後との相関はみられなかった. また, 固視部位および治療開始時 視力も予後を左右する因子とはなっていなかったが，固視状態はunsteadyの方が比較的予後が良好であっ た。治療開始時年齢を検討してみると，年齢が高いほど治りにくい傾向がみられ， 5 歳以下では治癒率 $43 \%$, 6 歳以上では $27 \%$ と低下していた。

幼小児において, 視力が悪い時点での固視検査は非常に難しく, 視力がある程度改善した時点で固視を再 検することの必要性を再認識させられた。
\end{abstract}

Predicting factors which significantly related with the prognosis of the amblyopia with eccentric fixation were evaluated.

Sixty children with amblyopia with eccentric fixation were treated by the occlusion therapy. The patients were forty-five esotropes, nine exotropes, two hypertropes, and four microtropes aged between two and twelve years (mean age : 5.6 years). The averaged initial corrected visual acity was (0.15). Eighty-three percent of the patients had the nasal eccentric fixation. The subjects who's corrected visual acuity reached to $(0.8)$ at the end of the occlusion therapy and successfully maintained for more than three months were concerned to be "cured".

Thirty-five percent of the patients were cured. The mean duration of the therapy was 17.1 months. Neither type of heterophoria, fixation area nor initial visual acuity had significant relation with the prognosis. Unsteady eccentric fixation was one of the predicting factors of be nign prognosis as well as the earlier beginning of the therapy. Although fouty-three percent of the patients who had started the treatment before five years in age were cared, only twenty-seven percent of the patients who had started occlusion after six years in age obtained the visual acuity over $(0.8)$.

In addition, we also recoginized that the fixation point of the patient should be re-examined after the visual acuity of the patient raised up to the certain level.

We conclude that, 1) the patient with un-

連絡先（干569）大阪府高槻市大学町 2 の 7 大阪医科大学眼科

TEL 0726-83-1221（内線2334）

Key words : 偏心固視, 健眼遮閉, 固視状態, unsteady，治療開始時年齢 steady eccentric fixation more easily recover the visual acuity than the patient with steady eccentric fixation, and 2) the occlusion therapy for the patients with eccentric fixation should be started before five years in age. 


\section{I . 緒言}

近年，偏心固視は減少してきているような印 象を持たれているが，当院では現在もなお偏心 固視患者の受診は多く，健眼遮閉を中心とした 治療を行っている．偏心固視の治療は年齢が低 いほど効果的ではある ${ }^{1)}$ が, 現実には低年齢者 の検査は難しく，固視状態を Visuscope で検査 するにはかなりの熟練を要し，視力の測定さえ 十分できない場合も多い。また長期間にわたる 遮閉の問題をはじめとして治療はなかなか難し い.

従来から「偏心固視の治療は極端な偏心固視 より，むしろ中心窩付近の固視のほうが奏功し やすい」という報告 ${ }^{1}$ があるが，私たちの経験か ら, 固視の偏心度の大きさは予後にあまり影響 しておらず，むしろ固視状態が予後に大きな影 響をもつのではないかという印象を持っている。 そこで今回は治療効果について検討する中から， 予後に影響を及ほす諸因子をはじめとする見直 しを行ったので報告する。

\section{II．対象および治療方法}

対象は内斜視 45 例, 外斜視 9 例, 上斜視 2 例, その他カバーテストで眼位のはっきりしない microtropia 4 例の計60例である. 治療開始時 年齢は 2 歳から12歳 (平均5.6歳) で, 治療開始 時視力は $0.15 \pm 0.15$, 弱視眼は右 23 眼, 左 37 眼 でやや左眼の方が多い傾向であった。

治療方法は完全矯正眼鏡の装用と健眼終日遮 閉を基本とし，経過により Moore-Johnson 変 法などを併用した。これまでと同様に ${ }^{2), 3)}$ 字ひと つ視力 (0.8) 以上が 3 力月以上安定して得られ た場合を治癒とみなした。本来，偏心固視の治 療においては，字ひとつ視力と字づまり視力を 比較検討する中での Crowding 現象の解消の有 無が治療効果を判定する上での大切なポイント となるが，今回は字づまり視力のデーターが不 十分なため残念ながら字ひとつ視力のみで結果 をまとめた。

\section{III. 結果}

\section{1．眼位と固視領域および治癒率}

眼位と固視領域およびその治癒率については 表 1 に示す。まず眼位と治癒率についてみると,

表 1 眼位と固視領域および治癒率

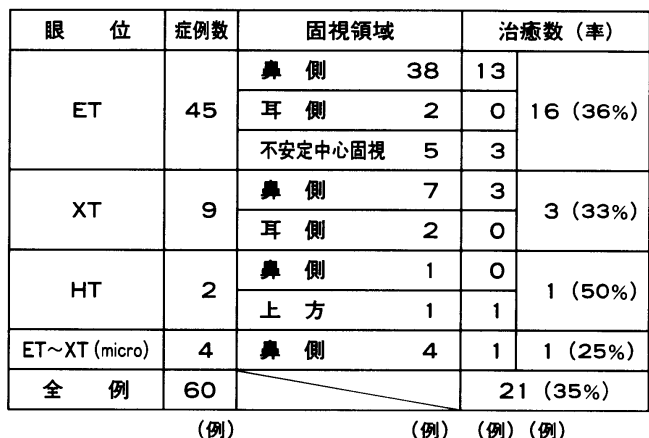

内斜視 $36 \%$, 外斜視 $33 \%$ と眼位による差はほと んどみられなかった。予後不良と言われている D. V.D.の合併に関しては，内斜視に 2 例, 外斜 視に 1 例みられたがそのうち内斜視の 1 例，外 斜視の 1 例の計 2 例は治癒, 残りの内斜視の 1 例も（0.7）の視力を得ることができており，特 に予後不良とは言えなかった。

固視領域について検討してみると，内斜視で は鼻側固視が38例で，耳側固視いわゆる paradoxical fixation は 2 例，中心窩を通る不安定 中心固視が 5 例，外斜視では鼻側固視いわゆる paradoxical fixation $か ゙ 7$ 例, 耳側固視は 2 例, 上斜視では鼻側と上方が各 1 例で, microtropia で眼位のはっきりしない症例では 4 例ともすべ て鼻側固視であった．固視領域に関しては，眼 位にかかわらず鼻側固視が多いことがわかった。 その治痛率についてみてみると, 鼻側固視 50 例 中17例 $(34 \%)$ が治癋し, 耳側固視では症例数 が 4 例と少ないが 1 例も治癒していない．全体 として，60例中21例（35\%）が治癒した。

\section{2. 固視部位および固視状態と視力予後}

固視部位と視力予後についての関係を表 2 に 
表 2 固視部位と視力予後

\begin{tabular}{|c|c|c|c|}
\hline \multirow{2}{*}{ 治療後の視力 } & \multicolumn{3}{|c|}{ 治療前の固視部位 } \\
\cline { 2 - 4 } & 周 辺 & 黄 斑 & 傍中心窝 \\
\hline $\begin{array}{c}\mathrm{V}<0.2 \\
\text { (視力不変) }\end{array}$ & 4 & 1 & 2 \\
\hline $0.2 \leqq V<0.8$ & 7 & 5 & 21 \\
\hline $\begin{array}{c}0.8 \leqq V \\
(\text { 予後良好) }\end{array}$ & 7 & 2 & 12 \\
\hline
\end{tabular}

(例)

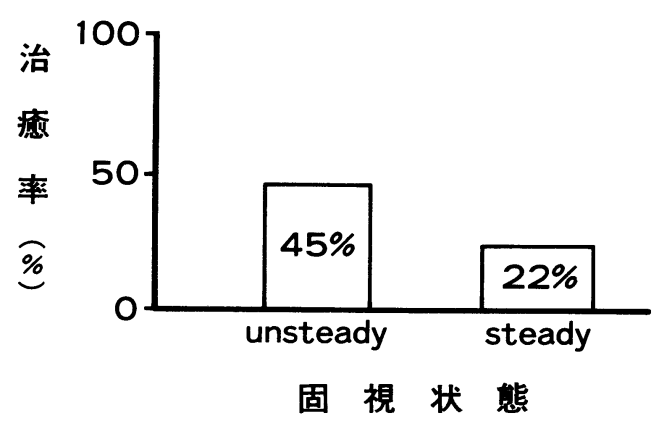

図 1 固視状態と治癒率

示す. 予後良好グループにも周辺固視が 7 例も 含まれており，偏心度の大きさと予後との一定 の関係はみられなかった。一方, 固視状態を steady か unsteady かに分けて治癒率をみてみ ると図 1 のように, unsteady では45\%, steady では $22 \%$ が治痛し, unsteady の方が治りやすい 傾向がみられた $\left(\mathrm{p}<0.05, \mathrm{X}_{0}^{2}\right.$ 検定 $)$

しかし，治癒した症例の中でもVisuscope に よる固視検査では固視が中心固視まで改善しな かった例（偏心度 $1^{\circ} \sim 1.5^{\circ}$ ）が 3 例みられた。 また治瘾しなかった例の多くはある程度の固視 の改善はみられたものの parafoveal steady と して偏心度 $1^{\circ}$ 程度で固定してしまう症例が多 く視力 (0.5) 前後で治療を中止したケースも少 なくない. 全症例のうち視力 $(0.5)$ 以上を得た ものは $68 \%$ であった。

\section{3. 治療開始時視力と治癒率および治療期間}

治療開始時視力と治療率および治療期間につ
表 3 治療開始時力と視力予後および治療期間

\begin{tabular}{|c|c|c|c|}
\hline 治療後の視力 & 症例数 & 治㞠開始時視力 & 治療期間 \\
\hline $\begin{array}{l}\mathrm{V}<0.2 \\
\text { (視力不変) }\end{array}$ & 7 & $0.06 \pm 0.03$ & $\begin{array}{l}\text { 治㞠中止 } \\
\text { までの期間 } \\
(6.8 \pm 6.1) \\
\end{array}$ \\
\hline $0.2 \leqq V<0.8$ & 32 & $0.15 \pm 0.1$ & $15.5 \pm 8.5$ \\
\hline $\begin{array}{c}0.8 \leqq V \\
\text { (予後良好) }\end{array}$ & 21 & $0.15 \pm 0.15$ & $17.1 \pm 9.5$ \\
\hline
\end{tabular}

いて表 3 に示す．治療開始時視力はどのグルー プもほとんど同じ值となっており, 予後を左右 する因子とはなっていなかった。それぞれのグ ループの治療期間をみてみると, 視力不変のグ ループは 6 カ月ないし 1 年の時点で予後を予測 して治療続行か中止かを決定していく関係上, 平均6.8力月と短く, 視力 $(0.2)$ 以上 $(0.8)$ 末 満のグループは平均 15.5 力月，(0.8）以上のグ ループは平均17.1力月ともっとも長い期間を要 していた。

\section{4. 治療開始年齢と治癒率}

全症例の治療開始年齢別の治痛数を図 2 に示 す. 斜線の入った部分が治癒した症例を表して いる.これをまとめてみると図 3 のようになり, 5 歳以下では治癒率 $43 \%, 6$ 歳以上では $27 \%$ と なりやはり治療開始時年齢が高いほど治りにく い傾向がみられた。

\section{5. 不同視の合併}

不同視の合併と治癒率について表 4 に示す. 眼位には関係なく，ほぼ同じ率で不同視が合併 しており，全体としては60例中24例 $(40 \%)$ に 不同視の合併がみられた. Microtropia の 4 例 中不同視の合併している 2 例は予後が悪かった。 また，不同視が合併した症例で治癒に至った 7 例のうち，3 例は初診時に偏心固視と診断した ものの, 治療後に両眼視機能が視差度 $70 \mathrm{sec}$ of $\operatorname{arc}$ まであることが判明したことからしても， 実は典型的な不同視弱視であったものと思われ る. 


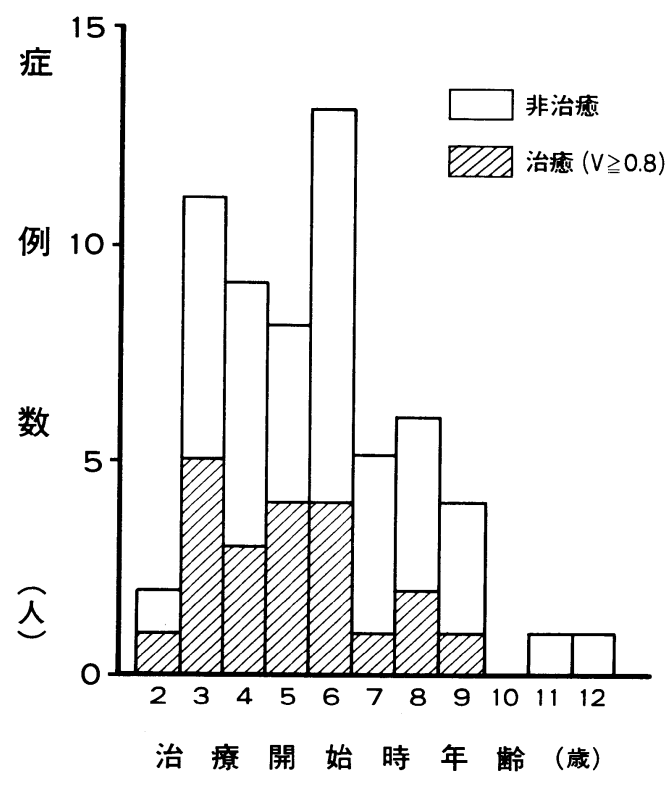

図 2 治療開始時年齢と治痛数

表 4 不同視の合併率と治癒率

\begin{tabular}{|c|c|c|}
\hline 眼位 & 不同視の合併 & 治瘾数 (率) \\
\hline $\mathrm{ET}$ & $18 / 45(40 \%)$ & $5 / 18(28 \%)$ \\
\hline $\mathrm{XT}$ & $4 / 9(44 \%)$ & $2 / 4(50 \%)$ \\
\hline $\mathrm{HT}$ & $0 / 2(0 \%)$ & \\
\hline $\begin{array}{c}\mathrm{ET} \sim \mathrm{XT} \\
\text { (micro) }\end{array}$ & $2 / 4(50 \%)$ & $0 / 2(0 \%)$ \\
\hline 全例 & $24 / 60(40 \%)$ & $7 / 24(29 \%)$ \\
\hline
\end{tabular}

(例)

(例)

\section{6. 偏心固視弱視と他の弱視との治療期間 および治癒率の比較}

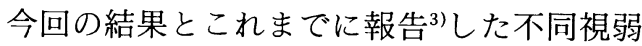
視および斜視弱視の結果を合わせて図 4 に示す. 棒グラフが治癒率を表し, 折れ線グラフが治療 期間を表す．治癒率は不同視弱視 $86 \%$ ，斜視弱 視 $59 \%$, 偏心固視弱視 $35 \%$ となっており，治療 期間は不同視弱視平均 7 力月, 斜視弱視平均 11 カ月，偏心固視弱視平均17.1力月であった。

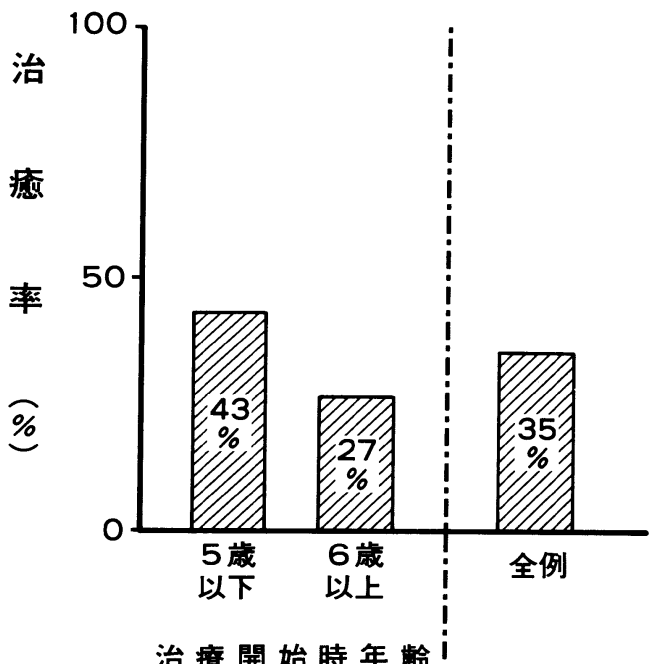

図3 治療開始時年齢と治瘾率

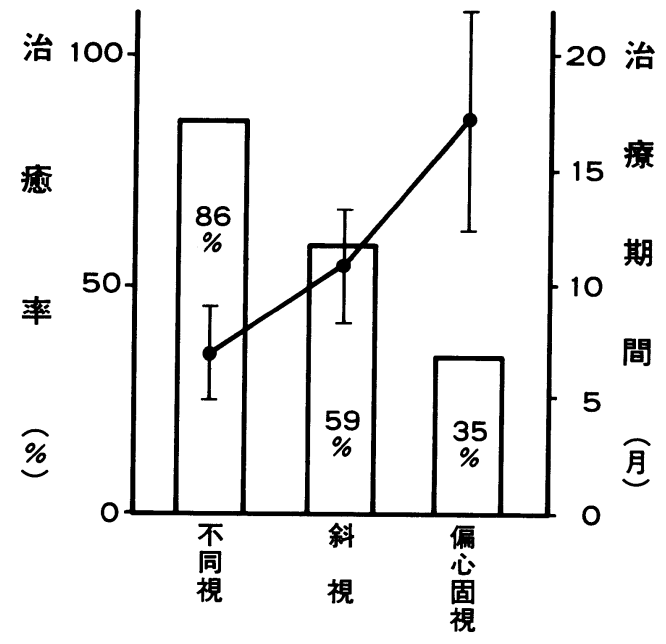

図 4 弱視のタイプ別の治療期間と治療率

\section{IV. 考按}

\section{1. 眼位と固視領域}

偏心固視の発生機序については, 従来より対 応説, 抑制暗点説, 運動異常説などの見解が出 されており, 実態は一つの説のみで簡単に説明 がつくほど単純なものではないことは周知のと 
おりである4).一般的には対応説を前提とした 表現方法が用いられている場合が多い。そこで 今回，眼位と固視領域との関連についてみてみ ると, 表 1 のごとく，眼位にかかわらず60例中 50例 $(83 \%)$ が鼻側固視で耳側固視は60例中 4 例 $(7 \%)$ しかなく，耳側固視は全例が治痛には いたらなかった．眼位と固視領域に相関が認め られず，そのほとんどが鼻側固視であったこと は過去の文献で報告されている内容と一致し た5).なぜ鼻側固視が多いのかについては，鼻側 網膜領域は発達期の優位性があるとされ，種及 の意見はあるものの推測の域を出ず，解明には 至っていない.

斜視のタイプとしては，従来から言われてい るとおり内斜視との合併が多く $75 \%$ を占め，外 斜視の合併は $15 \%$ であった。外斜視で偏心固視 を伴っている場合は，弱視が原発性で斜視は続 発性と考えられる症例が多く見られ6)，その代 表的なものとして粟屋らは形態覚遮断弱視を報 告し, 外斜視で鼻側固視いわゆる paradoxical fixation を呈するのがその特徵であると述べて (る7). しかし今回の症例には形態覚遮断の既 往のあるものはみられなかった。

また，D. V.D.の合併している症例は予後不 良という報告8もみられるが, 今回の D. V. D. 3 症例は最低でも視力 $(0.7)$ まで得ることがで き，必ずしも予後不良とはいいきれないと思わ れた。

\section{2. 固視部位と固視状態}

固視領域を細かく分けたり，steady か unsteady かに分けることなど実際には無意味で はないかという考え方もある。確かに固視の判 定において，最近はFundus Haploscope など により眼底直視下で固視点や対応関係が調べら れるようになったり ${ }^{9)}$, Visuscope などを用いず に両眼性の固視持続能力のチェックで固視不良 を鑑別する方法8),10)などをたくさんの報告がみ られる。またそれぞれの方法は今後, 臨床的に 役立つ固視検査法であると認められている。こ のように固視異常に関する表現方法は検查方法 などの変化により変わっていくものと思われる. ともあれ本報では，Visuscopeによる判定をも
とに，固視異常を従来どおりの方法で表現した。 文献的にみると, 正常者の視力曲線（ベルトハ イムの視力曲線）と比較すると，偏心固視部位 における視力は中心窩付近においても相当低く， 黄斑輪内 $\left(3.5^{\circ}\right.$ 以内) で視力 $(0.1) \sim(0.2)$, 黄 斑輪を越えるものは視力 $(0.1)$ 以下になると報 告されている(1) 16). とはいえ, 全体的に感度は 低いながらも周辺にいくほど低下している傾向 は示している.しかし，偏心固視がどのような 部位であろうとも, 治療に対する反応に差はみ られず，偏心度の大きさと予後との間に一定の 関係はみられなかった。

非治㾍例の中に parafoveal（偏心度 $1^{\circ}$ 程度） steady に固定して視力が (0.5) 前後に留まった 症例が多かったことからも，偏心固視眼の網膜 視感度曲線は正常者と異なり，必ずしも中心窩 が優位ではなく，黄斑輪内において，低いレべ ルでなだらかな視感度曲線を描いているものと 推測される。このことは, 近江ら ${ }^{11) ~ 15) か ゙ ~ F u n d u s ~}$ Haploscope を用いて偏心固視眼の視感度を測 定して描いた視感度分布と内容的に一致する。 一方，固視状態を steady か unsteady かに分け て検討してみると, steady では $22 \%$, unsteady では45\%が治癒し, unsteady の方が治りやすい 傾向がみられ，固視状態が有意に視力予後と関 連性を有していることも分かった。

\section{3. 不同視の合併}

不同視の合併は眼位に関係なくほぼ同じ率で みられ，全体として $40 \%$ に不同視の合併がみら れた. Microtropia で不同視の合併していた 2 例は予後が悪く，不同視で予後が悪い場合は， 初診時には鑑別が難しいが，microtropia や固 視異常が合併している場合が多いという従来か らの意見5),17)と一致している。

不同視が合併した症例で治瘾に至った 7 例の うち，3 例は初診時に偏心固視と診断したもの の, 治療後両眼視機能が視差度 $70 \mathrm{sec}$ of $\operatorname{arc} ま$ であることからして典型的な不同視弱視であっ た可能性が高い. 初診時の視力の悪い時点での 眼位検査や固視検査の難しさや不正確さは，検 者の熟練度だけでは解決でき個有の問題と考え られ，結局は鑑別の限界と言えるのかも知れな 
い.

\section{4. その他の因子について}

その他の因子について検討を行った結果，治 療開始時視力は平均 $(0.06) \sim(0.15)$ と全例ほ とんど同じ值を示し, 特に差異はみられなかっ た。

治療開始時年齢についてみると，やはり年齢 が高いほど治りにくい傾向が現れており，年歯 別治癋率で最も差がみられたのは 5 歳と 6 歳の 間であった。このことからも，就学前の治療の 重要性を再認識することができた。しかし，こ の結果より治療の年齢的な限界を線引きをする のが本報の目的ではなく，高年齢（12歳）でも 治療をすれば何らかの改善がみられたことから， 治療に対する協力性さえあればできる限り治療 すべきであると考える。

今回の結果を他の弱視の治瘺率や治療期間と 比較した結果から，偏心固視弱視がいかに治り にくく，また治療に時間がかかるかが明らかと なった。

\section{V. 結 論}

偏心固視を呈した弱視60例の治療成績につい て検討を行い，その中から予後に影響を及ぼす 諸因子の見直しを行ったところ，次のような知 見を得た。

1. 字ひとつ視力 $(0.8)$ を得て治㾍した症例は 60例中 21 例（35\%）で，治療期間は平均 17.1 カ月を要した。

2. 斜視のタイプと視力予後との関連はみられ なかった。

3. 治療前の固視領域や固視部位および治療開 始時視力は予後を左右する因子とはなってい なかった。

4. 固視状態と視力予後との間に関連性がみら れ, unsteady の方が比較的予後が良好であっ た.

5. 治療開始時年齢が高いほど治りにくい傾向 がみられ，5歳以下では治癒率43\%，6 歳以 上では $27 \%$ と低下していた。

6. 40\%に不同視の合併がみられた。

7. 幼小児において, 視力が悪い時点での固視
検查は非常に難しく，視力がある程度改善し た時点で固視を再検することの必要性を再認 識させられた。

（稿を終えるにあたり，御校閲いただきました 東 郁郎教授に心より深謝いたします.)

\section{文献}

1）深井小久子：Pleoptics, 眼科 Mook No. 10, 斜視 弱視 金原出版，東京，1979，p.230～245。

2）中村桂子，石田友規子，野邊由美子：MooreJohnson 変法による不同視弱視の治療と治療後 の調節について, 日本視訓練士協会誌 $13: 71 \sim 79$, 1985.

3）中村桂子，澤ふみ子，野邊由美子，溜村美恵子, 難波龍人，菅澤 淳，内海 隆：Moore-Johnson 変法による弱視治療について(続報), 眼臨医 82 ： 83〜88，1988,

4）植村恭夫：弱視の診断と治療，金原出版，東京， 1962.

5）平井淑江，三浦元也，川瀬芳克，伊藤照子：弱視 に伴う固視異常について，眼臨医 $77 ： 133 \sim 142$, 1983.

6）河原睦子，田中靖彦，植村恭夫：いわ沛る背理固 視を呈した外斜視の症例, 眼臨医81：1201〜 1203, 1987.

7）粟屋 忍：形態覚遮断弱視，あたらしい眼科 5： 979 984, 1988.

8）兒井千恵，久保田伸枝：内斜視に伴った固視不良 弱視の成因，眼臨医81：1195〜1200，1987。

9）小島とも急, 宇野史子, 末吉宏江, 新井真理：Fundus Haploscope に上る弱視患者の片眼固視と両 眼同時視の観察，眼臨医79：2136〜2141，1985.

10）臼井千恵，松岡久美子，久保田伸枝：固視不良弱 視の治療について，眼臨医79：2148～2153，1985。

11）乾 敏郎, 近江栄美子：赤外線 Fandus Haploscope による網膜対応の観察, 第12報偏心固視眼に 打ける視感度, 眼臨医77：2009 2012，1983。

12）近江栄美子, 乾 敏郎：正常眼扔よび偏心固視弱 視におけるフリッカー値と視感度の関係について, 日眼会誌 $91 ： 107 \sim 111 ， 1987$.

13）梅本真代，近江栄美子：偏心固視眼に抢ける固視 部位と視力との関係，眼臨医81：1187〜1189, 1987.

14）近江栄美子, 乾 敏郎：偏心固視弱視眼に打ける 固視部位と視力・ CEF および網膜対応との関係, 日眼会誌91：1291～1295，1987.

15）近江栄美子, 乾 敏郎：偏心固視弱視眼における 固視部位と視力との関係，眼臨医81：1187〜1189, 1987.

16) Von Noorden, G. K.: Binocular vision and ocular motility: theory and management of 
strabismus (3rd ed.) Mosby, St. Louis, 1985, p. $220 \sim 227$.

17) Everhard-Halm Y S, Maillette L J J M, Wenniger-prick de buy: Amblyopia treatment in microstrabismus, Brit. J. Ophthalmol., 46: 109 111, 1989.

\section{質問}

（東京医科歯科大）山下牧子

戻りの問題が訓練をしていて困ることの1つである
が戻りやすい症例というものがあれば教えて下さい. 答弁

今回の発表に戻りについては含めていないが, 治療 をやめても視力を維持しつづけるとは限らない．どの 症例についても戻りの可能性はあると思う。

追加 （大阪医大）内海 隆 今回の検查はオイチスコープでの固視状態であると いうことであって，その患者の固視はどこにあるかは 別の問題である. 